This article is available open access under a CC BY-ND 4.0 license as part of Berghahn Open Anthro, a subscribe-to-open model for APC-free open access made possible by the journal's subscribers.

\title{
FORUM
}

\section{STAYING TUNED}

\author{
Connections beyond 'the Field'
}

\section{Geoffrey Hughes and Anna-Maria Walter}

\begin{abstract}
Ethnographers today find themselves experimenting with new approaches to digital ethnography amid pandemic-related restrictions on research. Yet such developments only accelerate a broader trend toward the dissolution of the traditional ethnographic 'field' due to new communications technologies and the emergence of a globalized 'knowledge economy'. Through six contributions from around the world, this forum explores how the emergence of a more diffuse, interconnected ethnographic field is impacting fieldwork's status as a rite of passage, creating new affective entanglements and shifting power relationships between researchers and participants. Despite the potential for influence and surveillance that new technologies cede to already powerful institutions, the discussions underline how ethnographic interlocutors are auteurs in their own right - and that ethnographers are also often bit characters in other people's stories.
\end{abstract}

Keywords: agency, connectivity, ethnography, fieldwork, knowledge production, social media

Fittingly, this forum has emerged through the artifice of "Virtual Lisbon"- the response of the European Association of Social Anthropologists (EASA) to quarantine measures introduced in the wake of the COVID-19 pandemic, which made its planned annual conference in Lisbon in July 2020 impossible. Such online, socially distanced academic conferencing merely underlines the further dissolution of what was once quaintly termed the divide between 'the digital' and 'real life'. So while the pandemic has certainly accelerated the uptake of some digital practices, in other ways the very nature of sociality for the majority of the world's population has already been moving in that direction for the last 10 to 20 years due to the global mass introduction of Internet-enabled 
electronic devices. ${ }^{1}$ The generational shift that we are witnessing-before and after social media connectivity - has in turn profoundly transformed the experience of initiatory long-term fieldwork for the current cohort of anthropologists. They increasingly arrive in 'the field' with digital identities pre-formed and never really 'leave' since they remain accessible and accountable to their interlocutors as never before via the Internet. Especially at a moment when everyone is having to rethink social practices, we believe that the resultant unraveling and dissolution of 'the field' as it has traditionally been understood, and with it a shift in the power relations between researcher and interlocutors, requires theorization beyond 'digital ethnography' that can capture a novel yet increasingly pervasive human experience of 'staying tuned'.

What this forum looks into is not so much the methodological question of how to make sense of online connectivity, but rather how this new mode of interaction reflects a more ubiquitous shift in the relationship between ethnographer and research interlocutors that cannot be shunted into a sub-discipline of digital ethnography. With the initial adoption of these technologies, there emerged a huge canon of work on how to do ethnography of or in digital/virtual worlds, often structured around particular platforms such as the mobile phone (Horst and Miller 2006), Second Life (Boellstorff 2010), or Facebook (Miller 2011). However, every field nowadays contains some aspect of this shift, mostly through smartphones, which have become an integral part of life, not only in wealthy countries but even in some of the world's poorest regions, including those where this forum's organizers (Anna-Maria Walter and Geoffrey Hughes) work. This trend has been usefully theorized already as 'non-digital-centricness' (Pink et al. 2016), where the digital is simply part of the day-to-day background of community life rather than its organizing force and structure. The increasing banalization of the digital itself demands further theorization: it is ubiquitous, present in 'the field' and 'back home', sometimes fostering intense co-presence across great distances or even immense alienation at close quarters. Watching as people navigate between a range of digital and decidedly 'offline' identities also raises suspicions about how reliable either traditional or digitalcentric ethnographies ever were.

Since the field as envisioned by Malinowski, Boas, and their students was supposed to be far away from the academic landscape, even isolated in remote places, anthropologists initially took it upon themselves to bridge the geographical distance and act as cultural translators or ambassadors. But what happens after the researcher leaves? How is the connection maintained? And what are the implications of the recent availability of digital technologies for both ethnographers and their interlocutors? Through six complementary contributions from around the world, we explore how differently situated researchers are experiencing this extension or 'dissolution' of the field and explore how a recognition of the new role of ethnography within increasingly globalized 
knowledge-production economies (Hughes 2019) can help researchers grapple with the ethical challenges of engaging anthropologically with communities. One key factor here is more open and frank recognition of how anthropological interlocutors often have their own projects of self-fashioning, including aspects of self-objectification, curation, and cultural 'production' not so unlike the work of ethnographers themselves. Much as recent experiences of online conferencing embody new modalities of remote interaction with research partners that can be both empowering and agonizing (for all involved), so too were the specific fieldwork experiences that prompted the two forum convenors, Anna-Maria and Geoff, to think anew about these similarly fraught and unexpected connections.

Anna-Maria left her field site, Gilgit in northern Pakistan, in mid-2015. Although she has been to Pakistan since, she was able to return to the relatively remote mountain region only twice and for extremely short visits. While she was writing up her research findings on the intensification of relationships through mobile phones, especially how intimacy is established between future spouses, she experienced the opposite: despite the availability of smartphones her connections to Gilgit were slowly disintegrating. While expecting to carry on strong personal links from the field to home, she was instead struck by the affective challenges of long-distance communication. When the regular but now increasingly sporadic WhatsApp messages reach her from friends in Gilgit, they often go as follows: "Kya hal ha?" (How are you?). Not even waiting for an answer, they continue: "Miss uuuu" and "Ummmahhh," onomatopoetic for a kiss. Although signaling affection, the messages stay on a very superficial level. No matter how much Anna-Maria shares about her own life, she does not receive many personal details in return, or information about what is happening in her interlocutors' lives.

Early in mobile phone research, such modes of simply checking in were identified as important mechanisms to maintain a connection (Horst and Miller 2006). But the quickly fading intimacy of relationships triggered a feeling of selfdeception in Anna-Maria. Due to a high degree of 'empathic intimacy' (Walter 2019) during her fieldwork, she had eventually seen herself as an adopted family member and was called unili, or 'milk sister', in the local vernacular Shina. The mobile phone could not, however, serve as the "umbilical cord" (Palen et al. 2001: 113) that she had envisioned-and as it has been described for the connection between researcher and 'home'. The relationships with her interlocutors were obviously motivated by mutual interests and benefits, but they lost much of their appeal over distance. The young women who were the core focus group of her research are now most responsive when Anna-Maria simply sends pictures from her private life, above all baby pictures-something they display on their status updates or show off to others. While Anna-Maria values the ability to stay in touch for further questions and to witness her friends' Facebook activities, she has grown increasingly suspicious of the efficacy of digital 


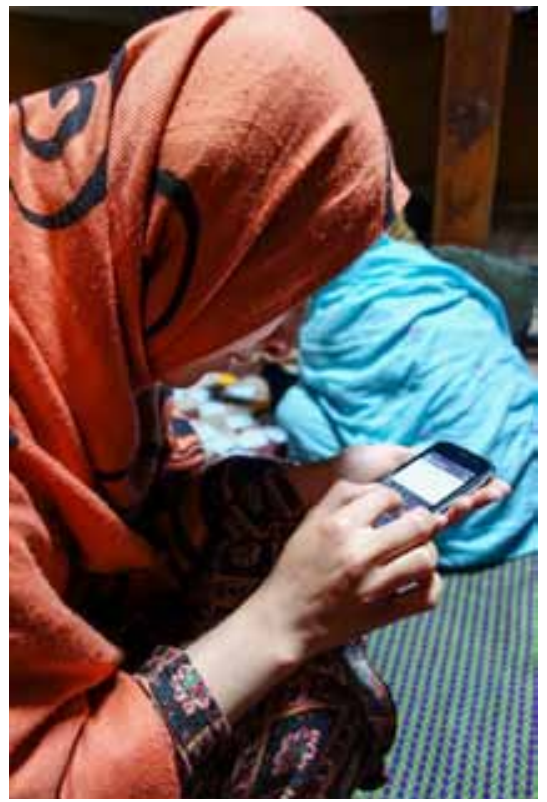

FiguRE 1: Young woman sending text messages from her phone, Gilgit, northern Pakistan, 2014. Photograph ${ }^{\circledR}$ Anna-Maria Walter

technologies for care and relationship work, especially when that connection is not at the same time strongly grounded in more immediate encounters. This example rather breaks the narrative of online connectivity as a panacea to bridge geographic distances. It highlights the 'terms of engagement' (Strathern 2020) that interlocutors set for the researcher when withdrawing from their daily lives, when leaving them. For many of Anna-Maria's friends, a synthesized one-on-one relationship disembodied from the wider village social context is not very rewarding; consequently, by neglecting to communicate digitally, they exert pressure on her to physically return.

Geoff's experience is one of the field reaching out and grabbing him with unexpected force. He was back home in Exeter sitting with his wife on a Saturday morning after a stint of research when he received a series of panicked WhatsApp messages from one of his Jordanian interlocutors-a Cambridgeeducated anthropologist, sometime intelligence officer, former member of Parliament, and now political dissident identified in this article as Dr. A. What immediately caught Geoff's eye was a picture of the two of them that must have been taken by someone following them when they had met at the library at Jordan University the week prior to discuss mutual interests in Jordanian politics and culture. In a series of memes and screenshotted conversations on Facebook, Geoff was accused of being a "Zionized agent," a creature of 
American intelligence, and other assorted treachery, while Dr. A was accused of being one of the "devils of the Hirak" - an anti-government social movement in Jordan dating back to before the Arab Spring. Dr. A had firm instructions: Geoff was to contact the US embassy and the FBI to inform them that rogue elements of Jordanian intelligence allied with the Queen were inciting violence against an American citizen. Having failed to convince Dr A that he could do nothing of the sort (because, after all, isn't that exactly what a spy would say?), Geoff eventually stopped responding to Dr. A's exhortations on the matter and decided to keep a lower profile in future.

In fact, Geoff had come to suspect that Dr. A himself was spreading rumors that he was a spy. While the fact that a man like Dr. A had the attention of foreign intelligence services might potentially disqualify him for political ambitions, it might valorize his claim of being a community leader. Yet even though Geoff was home and far away from any of the people behind the rumors who might wish him ill, the accusation hit him much harder than similar faceto-face accusations had in the past. The knowledge of being observed and objectified by hundreds of complete strangers debating his identity struck him as far more unnerving than a direct accusation from an individual (or handful of individuals). The resulting furor also left him deeply concerned that both he and research participants, who were more vulnerable and less assiduous in courting controversy, could be subject to similar accusations as retaliation for participating in Geoff's research. While nothing much came of the rumor after it had circulated online for a few days, the experience exemplifies how the terrain of ethnography is shifting in ways that deny ethnographers the ability to conduct fieldwork and tell their own stories on their own terms.

While Anna-Maria's experience features the diminishing affective dimensions of long-distance communication through mobile media over time, Geoff's

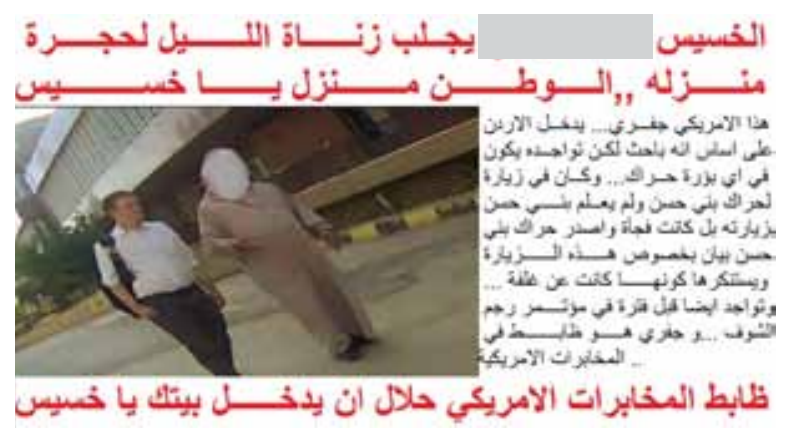

FiguRE 2: Part of a meme using a photograph taken by unknown persons following Geoff and Dr. A. It accuses Geoff of being an "American Intelligence Officer" and Dr. A of betraying the "homeland" by meeting with him. Source: Geoffrey Hughes 
experience shows that the researcher can be rendered present in interlocutors' lives even when gone-and it is a somewhat dubious presence that cannot be controlled. Both examples highlight how the agency of research participants, long acknowledged to exist during fieldwork, now increasingly persists over distance. When the field is able to reach out to the anthropologist back home, it not only dissolves clear divisions between work and private life, but, more importantly, brings with it a different dynamic between the interlocutors, a shift toward a more dyadic relationship that helps to highlight-and perhaps even somewhat correct-existing power asymmetries. This common denominator of connections beyond the field appears in all of the these contributions: they highlight strong partners and the agency that digital technologies offer them.

Through the different ways our research partners make use of new technologies to stay in touch with, employ, or scrutinize the anthropologist over distance, new (and not so new) methodological insights emerge that circle around the participatory element-or even collaborative effort-in knowledge production. These insights include how long-term fieldwork is not only a method of data collection but also a rite of passage, transforming the researcher into a full-fledged professional; how surfaces (digital or otherwise) may mask more complex underlying social realities that become revealed on closer, more intimate inspection; and how the ethnographic encounter is laden with complex power dynamics that demand careful ethical attention. Yet the emergence of an increasingly global and ubiquitous experience of the Internet also throws the inadequacy of previous attempts to resolve these issues into sharp relief, especially when ethnographers increasingly encounter their interlocutors as highly networked, media-savvy auteurs in their own right, with their own projects of cultural production and curation.

\section{Fieldwork as Initiation-and Its Dissolution}

Ethnographic fieldwork-especially an anthropologist's first experience of longterm fieldwork-has long been theorized variously as a literary device (Pratt 1986) and as a rite of passage (Wagner [1975] 2016). Within this paradigm of ethnographic validity established by Malinowksi and further stressed by Geertz (1988), 'being there' becomes central to the construction of anthropological authority, dramatized most vividly in the anthropologists' perpetual balancing act between empathic insider and neutral, attentively observing and analyzing outsider. However, this approach has also come in for sustained critique in recent years, not only for its othering, neo-colonial overtones (Chua 2015; Pratt 1986), but also for its failure to capture the realities of the digital age. For instance, Christine Hine (2015: 21) argues for a move beyond an episteme of "being there" toward one of "experience," which can include multiple forms of embodied as 
well as mediated practices. She pleads the case for mixed methods and multimodal approaches with face-to-face as well as mediated engagement, evolving and adapting to the research setting with the researcher acting as a "methodological pragmatist" (ibid.). Liana Chua (2015), who is a contributor to this forum, has argued for a shift from 'being there' toward 'co-presence'. She describes co-presence as a relational force of deeply entangled agents that make themselves felt for each other, rendering each other present in different moments and configurations. Both Hine and Chua have helped to demystify the transformative power of fieldwork- a key theme of the first two contributions to this forum.

Felix Girke begins the conversation by broaching an often ignored dimension of fieldwork: leaving the field. At least as traditionally envisioned and structured by university regulations, departmental norms, and the notion of 'writing up' reports, this phase was seen as far less problematic than that of building rapport, learning the local life-ways, and, as Mary Louise Pratt (1986) so perceptively noted, using those initial encounters as a topos for grounding the subsequent narrative. Yet like any rite of passage, fieldwork's successive stages of separation, liminality, and reintegration (van Gennep [1909] 2019) are all important for helping aspiring anthropologists move from one social category to another. Reflecting on his own moral qualms about leaving, Girke attempts a desacralization of fieldwork in keeping with the increasing dissolution of the field and a shift toward new approaches to engaging with field sites in a more connected world.

Chiara Cocco and Aleida Bertran, in contrast, give us a snapshot into the current struggles of $\mathrm{PhD}$ students to grapple with pandemic measures that not only challenge traditional fieldwork methods but also further complicate the modes of sociality they had intended to study. They focus on a pilgrimage whose continuation, especially due to its origins in response to a medieval plague, was seen as fraught yet essential. They explore the difficulties as well as the advantages of studying such religious festivals 'virtually' at the very moment when their interlocutors must experience the festival in the same way due to quarantine measures. In the end, both the pilgrims and the ethnographers were denied the transformative experience they had been expecting-of traveling long distances to glimpse esoteric truths and return anew, a connection made by, among others, Mary Helms (1988). Despite the obstacles and frustrations, Cocco and Bertran conclude that the whole experience proved nonetheless revealing, creating serendipitous moments of discovery.

In both cases, we come to appreciate the importance of focusing on the intersection of online and offline engagements-face-to-face as well as digital encounters. Reflecting increasingly hybrid forms of sociality, social media ethnography for these authors comes to act as an addition to, or rather an extension of, field immersion. As others have noted before, we can "understand the internet as a messy fieldwork environment that crosses online and 
offline worlds" (Postill and Pink 2012: 126). This hybrid approach allows Girke, Cocco, and Bertran to follow local people's avenues of knowledge production, much like our next pair of contributors.

\section{Affective Dimensions of Immediate and Distanced Modes of Communication}

The messiness of both online and offline worlds is a leitmotif of the next two contributions to the forum from Jason Scott and Nanneke Winters. Again, we see how both online and offline impressions can be distorting in isolation. The 'absent presence' (Gergen 2002) of on-site interaction can be compensated for with a 'connected presence' (Licoppe 2004) over distance, and intimacy can be created through mediated communication. At the same time, one can go overboard in embracing an overly 'liquid' ethnography, to borrow from Zygmunt Baumann (2000). The fleetingness and volatility—or in Baumann's terms, fluidity and liquidity—of online ethnographic encounters may distort our understandings of modes of sociality unfolding in more stereotypical ethnographic spaces, just as first impressions of a person can be misleading.

To illustrate the pitfalls of digital ethnography, Jason Scott juxtaposes his experience of abolitionist political organizing in Brazil's favelas with his more unsatisfying attempts to follow events from afar. Starting with a horrific shooting of a child by police that happened near him and in very intimate, close quarters, Scott traces out the trajectory of one of many 'failed' struggles for justice and relief from police violence. While living in the community with activists and watching the subtle interplay of online and offline struggles over tactics, resources, and leadership roles, he comes to despair of doing justice to the complexity of the struggle from afar. By embracing failure as an analytic shared with his interlocutors, Scott seeks to mobilize its generativity, showing how moments of disruption and frustrated intentionality in these movements can teach digital ethnographers to find new ways of conceptualizing experiences that are not made in place.

In contrast, Nanneke Winters writes of how online research made new dimensions of transnational migration available to her research while also empowering her interlocutors to engage with her on their own terms. Using the story of one woman she met under dire circumstances, Winters develops a parallel between her interlocutor's curatorial self-presentation online and older (i.e., pre-social media) concerns of impression management. She notes in particular how asynchronous communication can accommodate different time zones and schedules while also allowing people in difficult circumstances more control over how they are perceived. Against a well-rehearsed critique of social media as promoting surface appearances, Winters notes that while her work on 
people on the move often led her to see people at their lowest point, they could only express themselves on their own terms over time as they returned to their feet and moved on with their various online and offline projects.

Both contributions offer insights into the opacity of human encounter. Contrasting the capacities of one's interlocutors for curatorial intervention and self-presentation, both on- and offline, allows anthropologists to draw conclusions about the affective dimensions of the ethnographer's involvement with and interpretation of them. The case of Scott's online activists and of Winters's interlocutor's selective engagement with her also point toward a field that has almost been forgotten in the hype around global connectivity: the digital divide - or who is not present(ed) on digital media.

\section{Shifts in Power Asymmetries between Researcher and Interlocutors}

The final pairing of contributions to this forum, by Rosa Cordillera A. Castillo and Liana Chua, further enquire into digital technologies' interactive dimension. While ethnography is inherently collaborative, more widespread access to and use of phones and the Internet challenge ethnographic authority and could lead to an even greater democratization of the practice. At the same time, it would be an understatement to say that while the participatory aspects of technology are already here, they remain unevenly distributed. Governments, large organizations, and businesses can not only use their resources and the law to dominate discourse online; they can also engage in surveillance and intimidation tactics designed to shape debates and silence marginalized voices.

Castillo uses her sudden brush with notoriety, when her critique of the Philippine government's counter-terrorism policies 'went viral', to illustrate how the digital presentation of research findings connects the desk back to the field far more than print. While this can have the benefit of making findings more transparent and accessible, it also creates new challenges, especially for native anthropologists who feel a higher emotional and ethical responsibility to become active in the face of injustice. As news feeds with content from the field become omnipresent, any division between private and professional life that might have been easier to maintain before dissolves. Yet especially in light of revelations about how social media has been abused by authorities, Castillo notes that this leads to profound ethical dilemmas for digital ethnographers about the choice to use a medium that potentially exposes both researcher and researched at a time 'when Facebook is the Internet'.

In our final contribution, Liana Chua reflects upon her fieldwork encounters over time, both in her early 'village' ethnography and in her more recent research on activism around orangutan habitat conservation. She shows how 
the two research situations depend on the maintenance of certain self-fictions that can be either enhanced or threatened by the advent of the Internet and social media, including fears that her village interlocutors may discover she is not a practicing Christian and fears that conservationists may discover she is more interested in the rights of local communities than in orangutan preservation. Chua's example of creating productive fictions of oneself to 'fit' in the ethnographic setting raises important questions about ethnographers' selffashioning. Depending on context, the researcher's different facets move in and out of view, a dynamic that is strongly shaped by her interlocutors. Reflecting on the lack of transparency, Chua characterizes this as "partitioning and curating aspects of the ethnographic self-or having it curated by others-so as to become legible, legitimate, relatable to."

What both contributors highlight is how online self-presentation presents complex and not dissimilar dilemmas for researchers and interlocutors alike. The medium lends itself to the creation of a brand or 'digital persona' not unlike in face-to-face interaction. But the solution is not to hide or only internally negotiate these dilemmas, but rather to stress how certain aspects of one's persona are flexibly adapted to certain contexts, "like the role of an audio mixer or soundboard" (Abidin 2020: 58).
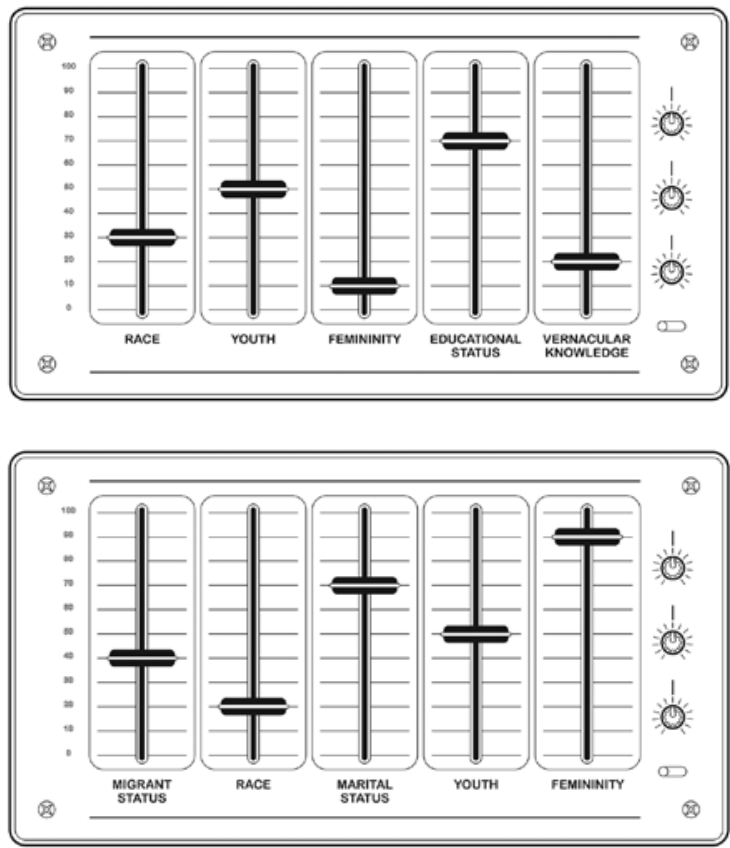

FIGURES 3 and 4: Images illustrated by mistercrow, commissioned by Crystal Abidin for Somewhere Between Here and There (2020) in Journal of Digital Social Research. 
In her afterword, Narmala Halstead encourages us to be skeptical of some of the promises of digital ethnography and to be aware of deeper continuities within the broader ethnographic tradition. Even as research participants become knowledge producers in their own right and gain new tools for challenging dominant ethnographic representations, she reminds us that dilemmas around managing the complexities of presence and absence have long defined ethnographic practice.

While Boellstorff et al. (2012) emphasize in their handbook of virtual fieldwork methods how staying in touch can be a demonstration of care and reciprocity, many of the contributors to this forum have had to accept that some of our interlocutors are not interested in prolonged intensive exchanges. Noting a common experience, Anna-Maria reports that when she is in Pakistan, her phone starts ringing, but at a distance she is the one who usually reaches out. This underlines a point that is sometimes elided-that anthropological interlocutors also have agency, reversing the equation in which the foreign researcher inevitably sets the terms of engagement. Again, this is not really new at all. As Nancy Baym (2015: 152) argues, "mediated communication is not a space, it is an additional tool people use to connect [or not], one which can only be understood as deeply embedded in and influenced by the daily realities of embodied life." What these tools allow is a new vantage point on much more long-standing social dynamics.

In a separate EASA panel on anthropology in the digital age, Daniel Miller (2020b) called for a 'defetishized theory' that not only addresses elites but is also understandable for 'everyone'. Here, theory is a means of translation rather an end in itself, a call that is well in tune with the trend of interlocutors following, scrutinizing, and mobilizing academic publications about 'them'. Miller urged anthropologists to acknowledge the post-colonial potential of digital technologies-especially through interlocutors' creative use of them and their collaborative aspect-as a self-critique of anthropology. More than a 'shift of regimes' (Miller 2020a) toward an online field, however, this collection of articles clearly shows how online connectivity needs to be embedded and contextualized in offline society, and how we need to critically reflect on the impact that our interlocutors' and our own social media use has for field relations more generally.

On a final note, these changing methodologies must take into account cutting-edge theorizations of the labor and power relations that continue to structure anthropological knowledge production-especially what Günel et al. (2020) call "feminist and decolonial theorizations of the intertwining of the personal and professional, the theoretical and the methodological in research." This leads 
them to advocate for a "patchwork ethnography" that combines short field trips and remote methods to keep up with changing demands of life (e.g., work-life balance, care responsibilities, environmental concerns, etc.), while living up to "long-term commitments, language proficiency, contextual knowledge, and slow thinking that characterizes so-called traditional fieldwork ... working with rather than against the gaps, constraints, partial knowledge, and diverse commitments that characterize all knowledge production" (ibid.). While this may not support a certain romantic vision of the anthropologist as a lone seeker, it nonetheless promises a useful challenge to entrenched inequalities inherent in the traditional ethnographic encounter while seeking to adapt to a changing global human condition.

\section{Acknowledgments}

This forum would not have been possible without the support of EASA, our wonderful contributors, and the editorial collective at Social Analysis.

Geoffrey Hughes is a Lecturer at the University of Exeter. His research explores how people in the contemporary Middle East work to reimagine a range of globally circulating technologies for large-scale population management, from the information infrastructures of government Sharia courts to the use of Facebook and other social media in blood feuds. He has conducted extensive fieldwork in Jordan funded by the US National Science Foundation, the National Endowment for the Humanities, and, more recently, the British Academy. His first book, Kinship, Islam and the Politics of Marriage in Jordan: Affection and Mercy, will be published by Indiana University Press in 2021. E-mail: g.hughes3@exeter.ac.uk

Anna-Maria Walter has worked on the anthropology of emotions, mobile phones, and changing ideas of love and marriage in the area of Gilgit in northern Pakistan funded by the German Research Council (DFG). Her monograph Intimate Connections will be published by Rutgers University Press in 2021 in its "Politics of Marriage and Gender" series. Following a fellowship at Exeter University, she is currently a Lecturer at the Institute of Social and Cultural Anthropology at LMU Munich. From 2021-2023, she holds a postdoctoral research fellowship at the University of Oulu (Finland), where she is part of an ERA.Net RUS Plus-funded project team working on conservation, tourism, and remoteness. E-mail: anna-maria.walter@ethnologie.lmu.de 


\section{Note}

1. The social media analytics tracker Hootsuite announced in July 2020 that some 3.96 billion people (the majority of the world's population of around 7.8 billion) are now on social media. Of course, should we exclude young children, this still leaves billions subject to an increasingly marked 'digital divide', and those who are excluded are impacted by this new social reality precisely through their exclusion (cf. Kemp 2020).

\section{References}

Abidin, Crystal. 2020. "Somewhere Between Here and There: Negotiating Researcher Visibility in a Digital Ethnography of the Influencer Industry." Journal of Digital Social Research 2 (1): 56-76.

Bauman, Zygmunt. 2000. Liquid Modernity. Cambridge: Polity Press.

Baym, Nancy K. 2015. Personal Connections in the Digital Age. Rev. ed. Cambridge: Polity Press.

Boellstorff, Tom. 2015. Coming of Age in Second Life: An Anthropologist Explores the Virtually Human. Rev. ed. Princeton, NJ: Princeton University Press.

Boellstorff, Tom, Bonnie Nardi, Celia Pearce, and T. L. Taylor. 2012. Ethnography and Virtual Worlds: A Handbook of Method. Princeton, NJ: Princeton University Press.

Chua, Liana. 2015. “Troubled Landscapes, Troubling Anthropology: Co-presence, Necessity, and the Making of Ethnographic Knowledge." Journal of the Royal Anthropological Institute 21 (3): 641-659.

Geertz, Clifford. 1988. Works and Lives: The Anthropologist as Author. Stanford, CA: Stanford University Press.

Gergen, Kenneth J. 2002. "The Challenge of Absent Presence.” In Perpetual Contact: Mobile Communication, Private Talk, Public Performance, ed. James E. Katz and Mark Aakhus, 227-241. Cambridge: Cambridge University Press.

Günel, Gökçe, Saiba Varma, and Chika Watanabe. 2020. "A Manifesto for Patchwork Ethnography.” Member Voices, Fieldsights, 9 June. https://culanth.org/ fieldsights/a-manifesto-for-patchwork-ethnography.

Helms, Mary W. 1988. Ulysses' Sail: An Ethnographic Odyssey of Power, Knowledge, and Geographical Distance. Princeton, NJ: Princeton University Press.

Hine, Christine. 2015. Ethnography for the Internet: Embedded, Embodied and Everyday. London: Bloomsbury Academic.

Horst, Heather A., and Daniel Miller. 2006. The Cell Phone: An Anthropology of Communication. Oxford: Berg.

Hughes, Geoffrey. 2019. "European Social Anthropology in 2018: An Increasingly Recursive Public.” Social Anthropology 27 (2): 352-372.

Kemp, Simon. 2020. “Global Social Media Overview.” DataReportal. https:// datareportal.com/social-media-users\#: :text = GLOBAL percent20Social percent20Media percent20OVERVIEW\&text $=$ As percent20of percent20July 
percent202020 percent2C percent20more, of percent20the percent20total percent20global percent20population.

Licoppe, Christian. 2004. “'Connected’ Presence: The Emergence of a New Repertoire for Managing Social Relationships in a Changing Communication Technoscape." Environment and Planning D: Society and Space 22 (1): 135-156.

Miller, Daniel. 2011. Tales from Facebook. Cambridge: Polity Press.

Miller, Daniel. 2020a. "How to Conduct an Ethnography during Social Isolation." YouTube, 3 May. https://www.youtube.com/watch? $\mathrm{v}=$ NSiTrYB-0so\&t = 1s.

Miller, Daniel. 2020b. "A Theory of a Theory of the Smartphone.” Global Anthropology in a Digital Age, EASA panel chaired by Katrien Pype and Daniel Miller, 21 June.

Palen, Leysia, Marilyn Salzman, and Ed Youngs. 2001. "Discovery and Integration of Mobile Communications in Everyday Life." Personal and Ubiquitous Computing 5 (2): 109-122.

Pink, Sarah, Heather Horst, John Postill, Larissa Hjorth, Tania Lewis, and Jo Tacchi. 2016. Digital Ethnography: Principles and Practice. London: Sage.

Postill, John, and Sarah Pink. 2012. "Social Media Ethnography: The Digital Researcher in a Messy Web.” Media International Australia 145 (1): 123-134.

Pratt, Mary Louise. 1986. "Fieldwork in Common Places." In Writing Culture: The Poetics and Politics of Ethnography, ed. James Clifford and George E. Marcus, 27-50. Berkeley: University of California Press.

Strathern, Marilyn. 2020. “Terms of Engagement.” EASA 2020 Opening and Keynote, 21 June. https://www.youtube.com/watch?v = YPKDVaxcYC8.

van Gennep, Arnold. (1909) 2019. The Rites of Passage. 2nd ed. Trans. Monika B. Vizedom and Gabrielle L. Caffee. Chicago: University of Chicago Press.

Wagner, Roy. (1975) 2016. The Invention of Culture. 2nd ed. Chicago: University of Chicago Press.

Walter, Anna-Maria. 2019. "Embodying Ineffable Concepts: Empathic Intimacy as Tool for Insight.” In Affective Dimensions of Fieldwork and Ethnography, ed. Thomas Stodulka, Samia Dinkelaker, and Ferdiansyah Thajib, 143-156. Cham: Springer. 